Nevada

Environmental Management Operations Activity

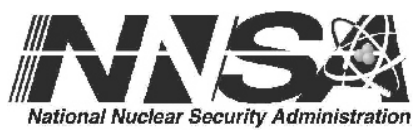

Corrective Action Plan for Corrective Action Unit 366: Area 11 Plutonium Valley Dispersion Sites, Nevada National Security Site, Nevada

Controlled Copy No.:

Revision: 0

April 2013 


\title{
DISCLAIMER
}

Reference herein to any specific commercial product, process, or service by trade name, trademark, manufacturer, or otherwise, does not necessarily constitute or imply its endorsement, recommendation, or favoring by the U.S. Government or any agency thereof.

This report has been reproduced directly from the best available copy.

Available for sale to the public from:

\author{
U.S. Department of Commerce \\ National Technical Information Service \\ 5301 Shawnee Road \\ Alexandria, VA 22312 \\ Telephone: (800) 553-6847 \\ Fax: (703) 605-6900 \\ E-mail: orders@ntis.gov \\ Online ordering: http://www.ntis.gov/help/ordermethods.aspx
}

Available electronically at http://www.osti.gov/bridge.

Available for a processing fee to the U.S. Department of Energy and its contractors, in paper, from:

U.S. Department of Energy

Office of Scientific and Technical Information

P.O. Box 62

Oak Ridge, TN 37831-0062

Telephone: (865) 576-8401

Fax: (865) 576-5728

E-mail: reports@adonis.osti.gov 


\title{
CORRECTIVE ACTION PLAN FOR CORRECTIVE ACTION UNIT 366: AREA 11 PLUTONIUM VALLEY DISPERSION SITES, NEVADA NATIONAL SECURITY SITE, NEVADA
}

\author{
U.S. Department of Energy \\ National Nuclear Security Administration \\ Nevada Field Office \\ Las Vegas, Nevada
}

Controlled Copy No.

Revision: 0

April 2013 
THIS PAGE INTENTIONALLY LEFT BLANK 


\section{CORRECTIVE ACTION PLAN FOR CORRECTIVE ACTION UNIT 366: AREA 11 PLUTONIUM VALLEY DISPERSION SITES, NEVADA NATIONAL SECURITY SITE, NEVADA}

Approved By: $\begin{aligned} \text { /s/: Tiffany A. Lantow } \\ \text { Tiffădify A. Lantow } \\ \text { Soils Activity Lead }\end{aligned}$

Approved By: /s/: Robert F. Boehlecke

Robert F. Boehlecke

Environmental Management Operations Activity Manager
Date: $4 / 10 / 2013$

Date: $4 / 10 / 2013$ 
THIS PAGE INTENTIONALLY LEFT BLANK 


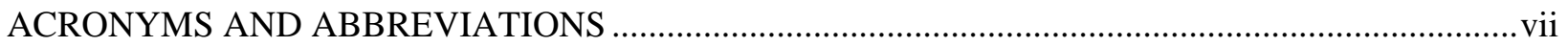

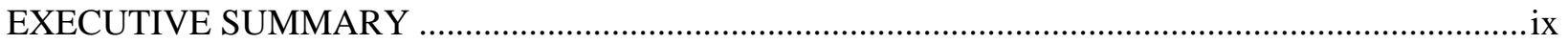

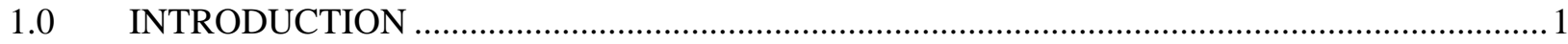

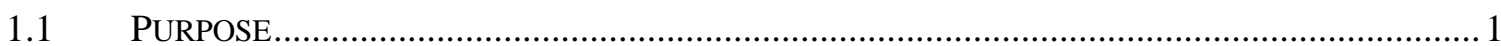

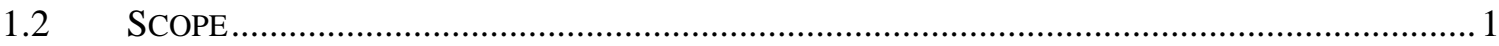

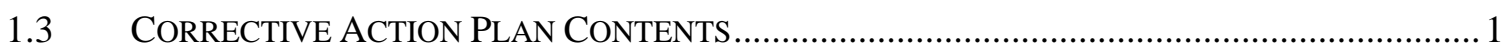

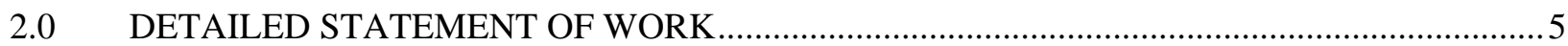

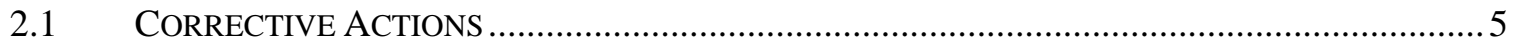

2.1.1 No Further Action............................................................................................ 5

2.1.1.1 Corrective Action Site 11-23-01, Radioactively Contaminated

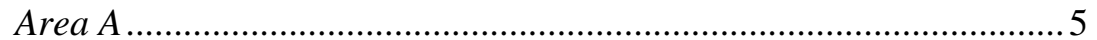

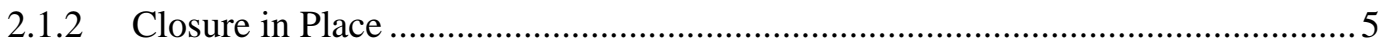

2.1.2.1 Corrective Action Site 11-08-01, Contaminated Waste Dump \#1 ....... 5

2.1.2.2 Corrective Action Site 11-08-02, Contaminated Waste Dump \#2 ....... 7

2.1.2.3 Corrective Action Site 11-23-02, Radioactively Contaminated Area B ............................................................................................ 8

2.1.2.4 Corrective Action Site 11-23-03, Radioactively Contaminated

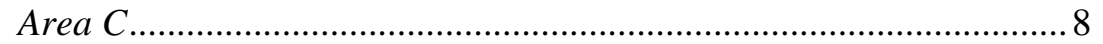

2.1.2.5 Corrective Action Site 11-23-04, Radioactively Contaminated

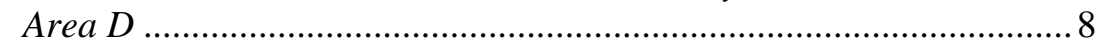

2.1.2.6 Best Management Practices ........................................................... 8

2.2 CONSTRUCTION QUALITY ASSURANCE/QUALITY CONTROL ............................................

2.2.1 Construction Field Sample Collection Activities .................................................. 9

2.2.2 Construction Laboratory/Analytical Data Quality Indicators ................................. 9

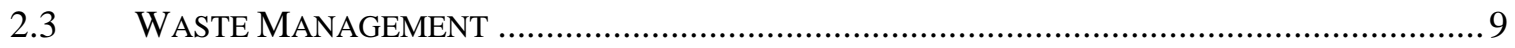

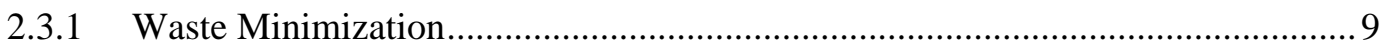

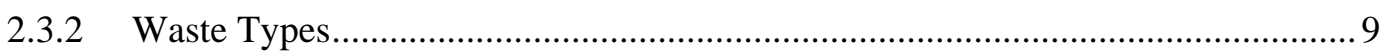

2.3.2.1 Sanitary Waste ............................................................................... 9

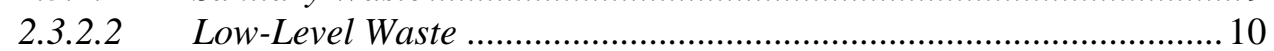

2.3.2.3 Decontamination Waste ................................................................ 10

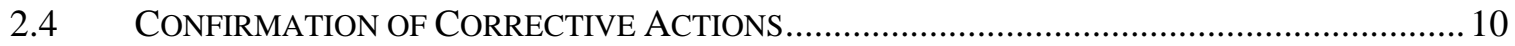

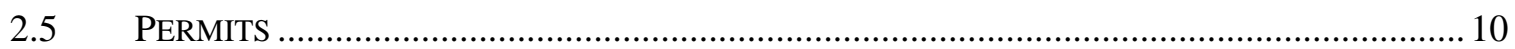

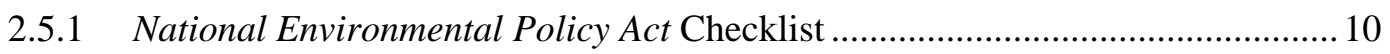

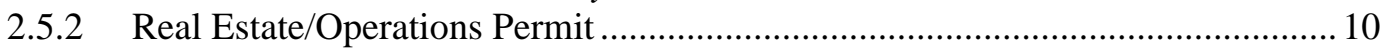

2.5.3 Radiological Work Permit ........................................................................... 10

2.5.4 Utility Clearances, Excavation Permits, and Blind Penetration Permits .............. 11

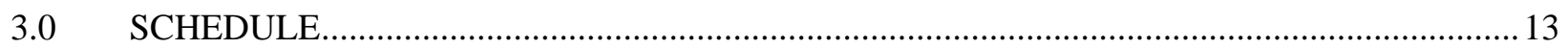

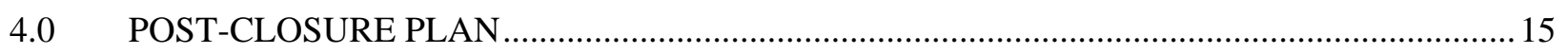

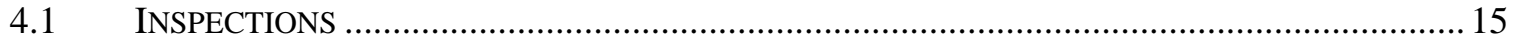

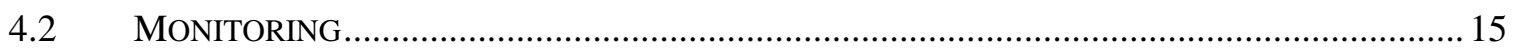

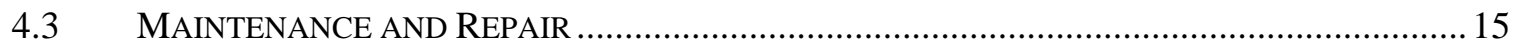

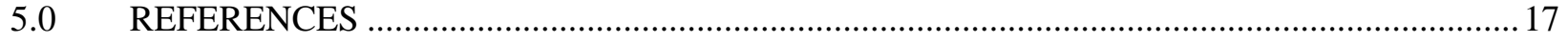

LIBRARY DISTRIBUTION LIST 


\section{LIST OF FIGURES}

Figure 1. Corrective Action Unit 366 Site Location MaP

Figure 2. Corrective Action Site LoCATIONS ANd PRoposed Use Restriction BOUNDARIES

\section{LIST OF TABLES}

TABle 1. Corrective ACtion Unit 366 Closure Activities

\section{LIST OF APPENDICES}

APPENDIX A. ENGINEERING SPECIFICATIONS AND DRAWINGS

APPENDIX B. SAMPLING AND ANALYSIS PLAN

APPENDIX C. ACTIVITY ORGANIZATION 


\section{ACRONYMS AND ABBREVIATIONS}

\begin{tabular}{|c|c|}
\hline CA & Contamination Area \\
\hline CADD & Corrective Action Decision Document \\
\hline CAP & Corrective Action Plan \\
\hline CAS & Corrective Action Site \\
\hline CAU & Corrective Action Unit \\
\hline $\mathrm{COC}$ & contaminant of concern \\
\hline CWD & contaminated waste dump \\
\hline DQI & data quality indicator \\
\hline FAL & final action level \\
\hline FFACO & Federal Facility Agreement and Consent Order \\
\hline $\mathrm{ft}$ & foot (feet) \\
\hline $\mathrm{HCA}$ & High Contamination Area \\
\hline LLW & low-level waste \\
\hline mrem/OU-yr & millirem(s) per Occasional Use Area year \\
\hline NDEP & Nevada Division of Environmental Protection \\
\hline NNSA & U.S. Department of Energy, National Nuclear Security Administration \\
\hline NNSA/NSO & $\begin{array}{l}\text { U.S. Department of Energy, National Nuclear Security Administration } \\
\text { Nevada Site Office }\end{array}$ \\
\hline PPE & personal protective equipment \\
\hline $\mathrm{QA} / \mathrm{QC}$ & quality assurance/quality control \\
\hline REOP & Real Estate/Operations Permit \\
\hline RMA & Radioactive Material Area \\
\hline RWP & Radiological Work Permit \\
\hline TED & total effective dose \\
\hline UR & use restriction \\
\hline URMA & Underground Radioactive Material Area \\
\hline
\end{tabular}


CAU 366 CAP

Section: Acronyms and Abbr.

Revision: 0

Date: April 2013

THIS PAGE INTENTIONALLY LEFT BLANK 


\section{EXECUTIVE SUMMARY}

This Corrective Action Plan has been prepared for Corrective Action Unit (CAU) 366, Area 11 Plutonium Valley Dispersion Sites, in accordance with the Federal Facility Agreement and Consent Order (FFACO, 1996 as amended). CAU 366 consists of the following six Corrective Action Sites (CASs) located in Area 11 of the Nevada National Security Site:

- CAS 11-08-01, Contaminated Waste Dump \#1

- CAS 11-08-02, Contaminated Waste Dump \#2

- CAS 11-23-01, Radioactively Contaminated Area A

- CAS 11-23-02, Radioactively Contaminated Area B

- CAS 11-23-03, Radioactively Contaminated Area C

- CAS 11-23-04, Radioactively Contaminated Area D

Site characterization activities were performed in 2011 and 2012, and the results are presented in Appendix A of the Corrective Action Decision Document (CADD) for CAU 366

(U.S. Department of Energy, National Nuclear Security Administration Nevada Site Office [NNSA/NSO], 2012a). The following closure alternatives were recommended in the CADD:

- No further action for CAS 11-23-01

- Closure in place for CASs 11-08-01, 11-08-02, 11-23-02, 11-23-03, and 11-23-04

The scope of work required to implement the recommended closure alternatives includes the following:

- Non-engineered soil covers approximately 3 feet thick will be constructed at CAS 11-08-01 over contaminated waste dump (CWD) \#1 and at CAS 11-08-02 over CWD \#2.

- FFACO use restrictions (URs) will be implemented for the areas where the total effective dose (TED) exceeds the final action level (FAL) of 25 millirems per Occasional Use Area year (mrem/OU-yr). The FAL is based on an assumption that the future use of the site includes occasional work activities and that workers will not be assigned to the area on a regular basis. A site worker under this scenario is assumed to be on site for a maximum of 80 hours per year for 5 years. The FFACO UR boundaries will encompass the areas where a worker would be exposed to 25 millirems of radioactivity per year if they are present for 80 hours per year. These boundaries will be defined as follows:

- It is assumed that radiological contaminants are present at CAS 11-08-01 and CAS 11-08-02 within CWDs \#1 and \#2 at levels exceeding the FAL. Therefore, UR boundaries will be established around the perimeters of the soil covers that will be constructed at CWD \#1 and CWD \#2. A geophysical survey revealed buried metallic debris outside the fence and adjacent to CWD \#1. Therefore, the UR boundary for CWD \#1 will be expanded to include the mound containing buried material.

- It is assumed that radiological contaminants are present at CAS 11-23-02, CAS 11-23-03, and CAS 11-23-04, within the three High Contamination Area (HCA) boundaries associated with the 11b, 11c, and 11d test areas at levels exceeding the FAL. Therefore, the UR boundaries will be established around the perimeters of the HCAs. The TED at an area of soil impacted by radiological debris outside the fence and adjacent to the 11c test area HCA exceeds the FAL of 25 mrem/OU-yr. Because the radiological impact from the debris at this location is visible on the aerial flyover 
radiological survey, all other areas within this isopleth of the flyover survey are conservatively also assumed to exceed the FAL. Therefore, the UR boundaries for the 11b, 11c, and 11d test areas will be expanded to include the areas within this isopleth.

- The FFACO URs will all be located within the large Contamination Area (CA) that encompasses Plutonium Valley. Because access to the CA is limited and entry into the CA for post-closure inspections and maintenance would be impractical, UR warning signs will be posted along the existing CA fence.

In accordance with the Soils Risk-Based Corrective Action Evaluation Process (NNSA/NSO, 2012b), an administrative UR will be implemented as a best management practice for the areas where the TED exceeds 25 millirems per Industrial Area year. This limit is based on continuous industrial use of the site and addresses exposure to industrial workers who would regularly be assigned to the work area for an entire career (250 days per year, 8 hours per day, for 25 years). Establishing an administrative UR will prevent inadvertent exposure of workers to radioactivity if a more intensive use of the site were to be considered in the future.

As a precautionary measure, the administrative UR boundary will be expanded to include the areas where removable contamination is present that exceeds the criterion for a CA. This will further ensure that workers will not perform future activities within this area without being notified of the presence of site contaminants. Therefore, the administrative UR boundary will be established around the perimeters of the large CA that encompasses the site and the CAs associated with the decontamination station and hot park. 


\subsection{INTRODUCTION}

This Corrective Action Plan (CAP) has been prepared in accordance with the Federal Facility Agreement and Consent Order (FFACO, 1996 as amended). Corrective Action Unit (CAU) 366, Area 11 Plutonium Valley Dispersion Sites, is located in Area 11 of the Nevada National Security Site and consists of the following six Corrective Action Sites (CASs) (Figure 1):

- CAS 11-08-01, Contaminated Waste Dump \#1

- CAS 11-08-02, Contaminated Waste Dump \#2

- CAS 11-23-01, Radioactively Contaminated Area A

- CAS 11-23-02, Radioactively Contaminated Area B

- CAS 11-23-03, Radioactively Contaminated Area C

- CAS 11-23-04, Radioactively Contaminated Area D

\subsection{Purpose}

Site history and characterization results are provided in the Corrective Action Investigation Plan (U.S. Department of Energy, National Nuclear Security Administration Nevada Site Office [NNSA/NSO], 2011) and Corrective Action Decision Document (CADD) (NNSA/NSO, 2012a). This CAP presents the scope of work required to implement the recommended corrective actions, as specified in Section 4.0 of the CADD.

\subsection{SCOPE}

Closure activities include construction of non-engineered soil covers approximately 3 feet (ft) thick over contaminated waste dump (CWD) \#1 and CWD \#2 and implementation of use restrictions (URs) for the areas that exceed the final action level (FAL) of 25 millirems per Occasional Use Area year (mrem/OU-yr). Table 1 presents a summary of closure activities. Details are presented in Section 2.0.

\subsection{Corrective Action Plan Contents}

This CAP consists of the following sections and appendices:

- Section 1.0: Introduction

- Section 2.0: Detailed Statement of Work

- Section 3.0: Schedule

- Section 4.0: Post-Closure Plan

- Section 5.0: References

- Appendix A: Engineering Specifications and Drawings

- Appendix B: Sampling and Analysis Plan

- Appendix C: Activity Organization

- Library Distribution List 


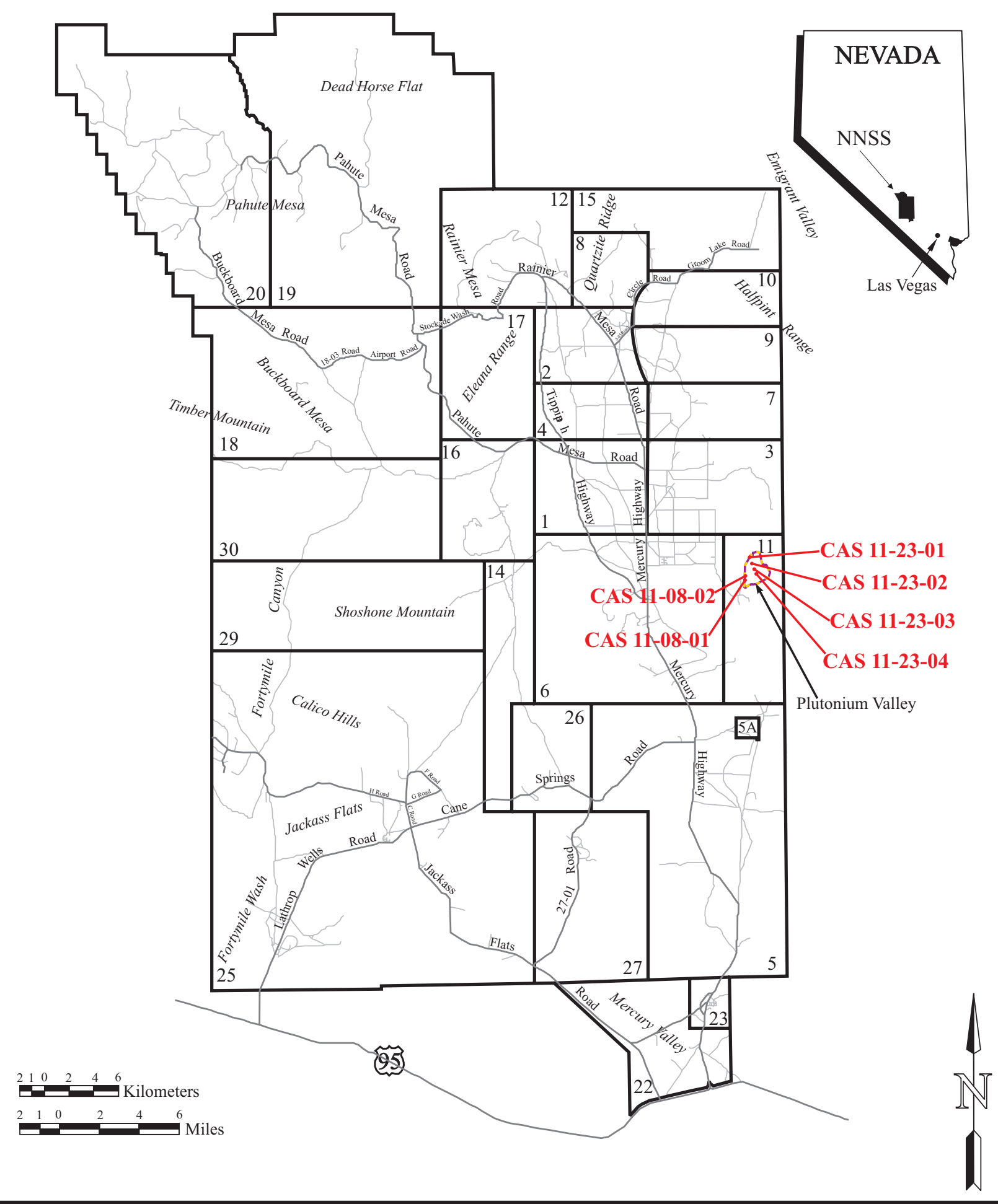

Figure 1. Corrective ACTION UNit 366 Site Location MaP 


\section{Table 1. Corrective Action Unit 366 Closure Activities}

\begin{tabular}{|c|c|c|c|c|}
\hline CAS & Name & Closure Method & COCs & Scope of Work \\
\hline $11-08-01$ & $\begin{array}{c}\text { Contaminated } \\
\text { Waste Dump \#1 }\end{array}$ & Closure in Place & Radiological & $\begin{array}{l}\text { - Construct a non-engineered soil cover approximately } 3 \mathrm{ft} \text { thick over the landfill. } \\
\text { - Place concrete monuments at the corners of the landfill cover, post UR warning } \\
\text { signs on the monuments and CA fence, and implement a UR around the perimeter } \\
\text { of the soil cover and adjacent mound containing buried metallic debris. }\end{array}$ \\
\hline $11-08-02$ & $\begin{array}{c}\text { Contaminated } \\
\text { Waste Dump \#2 }\end{array}$ & Closure in Place & Radiological & $\begin{array}{l}\text { - Construct a non-engineered soil cover approximately } 3 \mathrm{ft} \text { thick over the landfill. } \\
\text { - Place concrete monuments at the corners of the landfill cover, post UR warning } \\
\text { signs on the monuments and CA fence, and implement a UR around the perimeter } \\
\text { of the soil cover. }\end{array}$ \\
\hline $11-23-01$ & $\begin{array}{l}\text { Radioactively } \\
\text { Contaminated } \\
\text { Area A }\end{array}$ & No Further Action & None & None \\
\hline $11-23-02$ & $\begin{array}{l}\text { Radioactively } \\
\text { Contaminated } \\
\text { Area B } \\
\end{array}$ & Closure in Place & Radiological & $\begin{array}{l}\text { - Post UR warning signs on the CA fence and implement a UR for the HCA } \\
\text { associated with the } 11 \mathrm{~b} \text { test area and adjacent soil impacted by radiological debris. }\end{array}$ \\
\hline $11-23-03$ & $\begin{array}{l}\text { Radioactively } \\
\text { Contaminated } \\
\text { Area C }\end{array}$ & Closure in Place & Radiological & $\begin{array}{l}\text { - Post UR warning signs on the CA fence and implement a UR for the HCA } \\
\text { associated with the 11c test area and adjacent soil impacted by radiological debris. }\end{array}$ \\
\hline $11-23-04$ & $\begin{array}{l}\text { Radioactively } \\
\text { Contaminated } \\
\text { Area D }\end{array}$ & Closure in Place & Radiological & $\begin{array}{l}\text { - Post UR warning signs on the CA fence and implement a UR for the HCA } \\
\text { associated with the 11d test area and adjacent soil impacted by radiological debris. }\end{array}$ \\
\hline
\end{tabular}

CA: Contamination Area

CAS: Corrective Action Site

COC: contaminant of concern

ft: foot (feet)

HCA: High Contamination Area

UR: use restriction 
CAU 366 CAP

Section: Introduction

Revision: 0

Date: April 2013

THIS PAGE INTENTIONALLY LEFT BLANK 


\subsection{DETAILED STATEMENT OF WORK}

The approved corrective actions for CAU 366, as evaluated in Section 3.0 of the CADD and identified in Section 4.0 of the CADD (NNSA/NSO, 2012a), include the following:

- CAS 11-08-01, Contaminated Waste Dump \#1: Closure in Place

- CAS 11-08-02, Contaminated Waste Dump \#2: Closure in Place

- CAS 11-23-01, Radioactively Contaminated Area A: No Further Action

- CAS 11-23-02, Radioactively Contaminated Area B: Closure in Place

- CAS 11-23-03, Radioactively Contaminated Area C: Closure in Place

- CAS 11-23-04, Radioactively Contaminated Area D: Closure in Place

\subsection{CoRrective ACtions}

The corrective action alternatives are identified in the CADD (NNSA/NSO, 2012a) and were approved by the Nevada Division of Environmental Protection (NDEP).

\subsubsection{No Further Action}

\subsubsection{Corrective Action Site 11-23-01, Radioactively Contaminated Area A}

This site consists of the soil impacted as a result of safety experiment Project 56 No. 1. The safety experiment was detonated at test area 11a on November 1, 1955. The 11a test area is not fenced or posted as a High Contamination Area (HCA). No radiological contamination associated with the 11a test area was identified that exceeds the FAL of 25 mrem/OU-yr. Figure 2 shows the location of CAS 11-23-01.

\subsubsection{Closure in Place}

\subsubsection{Corrective Action Site 11-08-01, Contaminated Waste Dump \#1}

CWD \#1 was used to dispose of wooden structures that the test devices were placed in, sand that surrounded the test beds that became radiologically contaminated, contaminated clothing and equipment, and other items such as cable, metal, and various items associated with the test activities. CWD \#1 measures approximately 105 by $93 \mathrm{ft}$, and is posted as an Underground Radioactive Material Area (URMA). The URMA is located southwest of the four test areas within the large Contamination Area (CA) that encompasses Plutonium Valley. Figure 2 shows the location of CAS 11-08-01.

A non-engineered soil cover approximately 3 feet thick will be constructed over CWD \#1. Before construction of the cover, radiological surveys will be performed in a buffer area of approximately $50 \mathrm{ft}$ in the CA surrounding the CWD. In addition, the access route to the edge of the landfill will be surveyed. This will identify posting requirements for the work area around the CWD and for heavy equipment and personnel access. Clean fill may be placed in the work area to allow for downposting of the CA. Clean soil will then be placed over the CWD in lifts of approximately 6 inches and wheel rolled for compaction. The side slopes of the cover will be approximately 2:1. Concrete monuments will be installed at the corners of the landfill cover. 


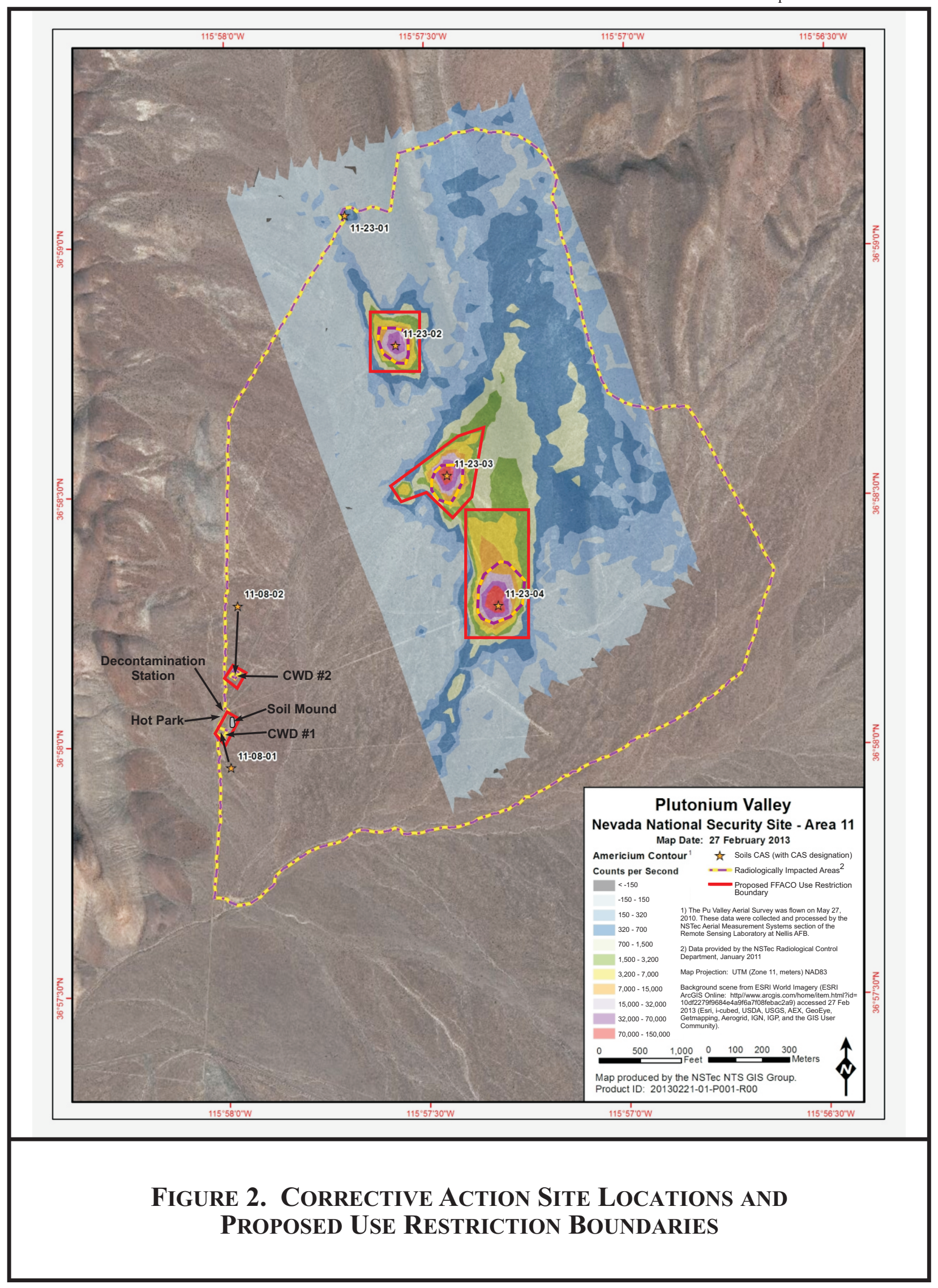


Because it is assumed that radiological contaminants are present within CWD \#1 at levels exceeding the FAL of 25 mrem/OU-yr, a FFACO UR will be implemented. The UR boundary will be established around the perimeter of the soil cover. In addition, a geophysical survey revealed buried metallic debris outside the fence and adjacent to CWD \#1. Therefore, the UR boundary for CWD \#1 will be expanded to include the mound containing buried material. Figure 2 shows the proposed UR boundary for CAS 11-08-01.

UR warning signs will be attached to the concrete monuments located at the corners of the landfill cover and along the existing CA fence that encompasses Plutonium Valley. The landfill, surrounding buffer area, and access route will be properly posted for radiological concerns per the Radiological Control Manual (Radiological Control Managers' Council, 2012). The access route to the landfill and surrounding buffer area are expected to be a Radioactive Material Area (RMA), and the landfill itself is expected to be an URMA. This will allow for more convenient access to the landfill for post-closure inspections and repairs, as entry to the landfill through a CA would be impractical.

\subsubsection{Corrective Action Site 11-08-02, Contaminated Waste Dump \#2}

CWD \#2 was used to dispose of wooden structures that held the test devices, radiologically contaminated sand that surrounded the test beds, contaminated clothing and equipment, and other items such as cable, metal, and various items associated with the test activities. CWD \#2 measures approximately 92 by $78 \mathrm{ft}$, and is posted as an HCA. Partially buried cable and other debris are visible within the boundary of CWD \#2. The HCA is located southwest of the four test areas within the large CA that encompasses Plutonium Valley. Figure 2 shows the location of CAS 11-08-02.

A non-engineered soil cover approximately 3 feet thick will be constructed over CWD \#2. The top of the soil cover will be at least 3 feet higher than the elevation of visible debris that was partially buried in the landfill. Before construction of the cover, radiological surveys will be performed in a buffer area of approximately $50 \mathrm{ft}$ in the CA surrounding the CWD. In addition, the access route to the edge of the landfill will be surveyed. This will identify posting requirements for the work area around the CWD for heavy equipment and personnel access. Clean fill may be placed in the work area to allow for downposting of the CA. Clean soil will then be placed over the CWD in lifts of approximately 6 inches and wheel rolled for compaction. The side slopes of the cover will be approximately 2:1. Concrete monuments will be installed at the corners of the landfill cover.

Because it is assumed that radiological contaminants are present within CWD \#2 at levels exceeding the FAL of 25 mrem/OU-yr, a FFACO UR will be implemented. The UR boundary will be established around the perimeter of the soil cover. Figure 2 shows the proposed UR boundary for CAS 11-08-02.

UR warning signs will be attached to the concrete monuments located at the corners of the landfill cover and along the existing CA fence that encompasses Plutonium Valley. The landfill, surrounding buffer area, and access route will be properly posted for radiological concerns per the Radiological Control Manual (Radiological Control Managers’ Council, 2012). The access route to the landfill and surrounding buffer area are expected to be an RMA, and the landfill itself is expected to be an URMA. This will allow for more convenient access to the landfill for post-closure inspections and repairs, as entry to the landfill through a CA would be impractical. 


\subsubsection{Corrective Action Site 11-23-02, Radioactively Contaminated Area B}

Date: April 2013

This site consists of the soil impacted as a result of safety experiment Project 56 No. 2. The safety experiment was detonated at test area $11 \mathrm{~b}$ on November 3,1955 . The $11 \mathrm{~b}$ test area is fenced and posted as an HCA. Figure 2 shows the location of CAS 11-23-02.

Because it is assumed that radiological contaminants are present within the HCA associated with the $11 \mathrm{~b}$ test area at levels exceeding the FAL of $25 \mathrm{mrem} / \mathrm{OU}-\mathrm{yr}$, a FFACO UR will be implemented. The UR boundary will be established around the isopleth of the aerial flyover radiological survey that corresponds to the isopleth in which radiological debris is located outside the fence and adjacent to the 11c test area HCA that exceeds the FAL of $25 \mathrm{mrem} / \mathrm{OU}-\mathrm{yr}$. Figure 2 shows the proposed UR boundary for CAS 11-23-02.

UR warning signs will be posted along the existing CA fence that encompasses Plutonium Valley.

\subsubsection{Corrective Action Site 11-23-03, Radioactively Contaminated Area C}

This site consists of the soil impacted as a result of safety experiment Project 56 No. 3. The safety experiment was detonated at test area $11 \mathrm{c}$ on November 5,1955 . The $11 \mathrm{c}$ test area is fenced and posted as an HCA. Figure 2 shows the location of CAS 11-23-03.

Because it is assumed that radiological contaminants are present within the HCA associated with the 11c test area at levels exceeding the FAL of 25 mrem/OU-yr, a FFACO UR will be implemented. The UR boundary will be established around the isopleth of the aerial flyover radiological survey that corresponds to the isopleth in which radiological debris is located outside the fence and adjacent to the 11c test area HCA that exceeds the FAL of 25 mrem/OU-yr. Figure 2 shows the proposed UR boundary for CAS 11-23-03.

UR warning signs will be posted along the existing CA fence that encompasses Plutonium Valley.

\subsubsection{Corrective Action Site 11-23-04, Radioactively Contaminated Area D}

This site consists of the soil impacted as a result of safety experiment Project 56 No. 4. The safety experiment was detonated at test area $11 \mathrm{~d}$ on January 18,1956 . The $11 \mathrm{~d}$ test area is fenced and posted as an HCA. Figure 2 shows the location of CAS 11-23-04.

Because it is assumed that radiological contaminants are present within the HCA associated with the 11d test area at levels exceeding the FAL of $25 \mathrm{mrem} / \mathrm{OU}$-yr, a FFACO UR will be implemented. The UR boundary will be established around the isopleth of the aerial flyover radiological survey that corresponds to the isopleth in which radiological debris is located outside the fence and adjacent to the 11c test area HCA that exceeds the FAL of 25 mrem/OU-yr. Figure 2 shows the proposed UR boundary for CAS 11-23-04.

UR warning signs will be posted along the existing CA fence that encompasses Plutonium Valley.

\subsubsection{Best Management Practices}

In accordance with the Soils Risk-Based Corrective Action Evaluation Process (NNSA/NSO, 2012b), an administrative UR will be implemented as a best management practice for the areas where the TED exceeds 25 millirems per Industrial Area year. This limit is based on continuous industrial use of the site and addresses exposure to industrial workers who would regularly be 
assigned to the work area for an entire career (250 days per year, 8 hours per day, for 25 years). Establishing an administrative UR will prevent inadvertent exposure of workers to radioactivity if a more intensive use of the site were to be considered in the future.

As a precautionary measure, the administrative UR boundary will be expanded to include the areas where removable contamination is present that exceeds the criterion for a CA. This will further ensure that workers will not perform future activities within this area without being notified of the presence of site contaminants. Therefore, the administrative UR boundary will be established around the perimeters of the large CA that encompasses the site and the CAs associated with the decontamination station and hot park.

\subsection{Construction Quality Assurance/Quality Control}

No engineered structures will be constructed. Therefore, a construction quality assurance/quality control (QA/QC) plan is not required.

\subsubsection{Construction Field Sample Collection Activities}

Field samples are not required to certify construction activities for closure of CAU 366.

\subsubsection{Construction Laboratory/Analytical Data Quality Indicators}

Closure activities are limited to construction of two non-engineered soil covers and implementation of URs. A construction QA/QC plan is not required, and construction data quality indicators (DQIs) are not applicable. To ensure that the material used to construct the covers remains consistent, all fill will be taken from an approved borrow source.

\subsection{WASTE MANAgEMENT}

Waste will be managed and disposed according to applicable federal and state regulations and company waste management procedures. Closure activities are expected to generate low-level waste (LLW) in the form of personal protective equipment (PPE) used during closure activities. Confirmation of waste disposal will be included in the CAU 366 Closure Report.

\subsubsection{Waste Minimization}

The volume of waste generated will be minimized to the maximum extent feasible. Waste will be properly characterized and segregated to avoid the generation of additional waste.

\subsubsection{Waste Types}

\subsubsection{Sanitary Waste}

Any sanitary waste generated (e.g., non-impacted PPE and general trash) and construction debris (e.g., wood, concrete, metal, plastic) removed from sites will be radiologically screened for free release (Radiological Control Managers' Council, 2012) and disposed as sanitary waste in an onsite permitted landfill. 


\subsubsection{Low-Level Waste}

PPE used during closure activities will be disposed as LLW. LLW will be managed and disposed according to all applicable federal and state regulations and company waste management procedures. LLW will be packaged under the guidance of a Waste Certification Official and Waste Generator Services personnel. LLW will be stored in a Radioactive Material Area until a waste disposal profile is prepared and approved, and transport to an appropriate disposal facility can be arranged.

\subsubsection{Decontamination Waste}

Equipment will be surveyed prior to release. Equipment that becomes contaminated will be decontaminated on site. Dry decontamination will be the preferred method. For larger pieces of equipment that cannot be effectively decontaminated using dry decontamination techniques, wet decontamination techniques will be used. Decontamination rinsate will be managed appropriately according to applicable regulations and, once characterized, properly disposed.

\subsection{CONFIRMATION OF CORRECTIVE ACTIONS}

Completion of corrective actions will be verified by visual inspection and photographic documentation of final site conditions. Verification samples are not required; therefore, a sampling and analysis plan and DQIs are not applicable.

\subsection{PERMits}

Prior to beginning closure activities, planning documents and permits will be prepared. These documents will include a National Environmental Policy Act Checklist, a Real Estate/Operations Permit (REOP), Radiological Work Permits (RWPs), and excavation/penetration permits.

\subsubsection{National Environmental Policy Act Checklist}

A National Environmental Policy Act Checklist will be completed prior to closure activities. Closure activities will follow all applicable federal, state, and local laws, regulations, and permits regarding protection of the environment.

\subsubsection{Real Estate/Operations Permit}

A REOP will be obtained prior to closure activities. The REOP is the work authorization document used by National Security Technologies, LLC, to authorize a scope of work with known risks, hazards, and hazard mitigations.

\subsubsection{Radiological Work Permit}

An RWP will be required. The RWP will inform workers of the specific PPE required and identify site-specific controls. Workers will be required to sign the RWP and acknowledge their understanding of the requirements before entry into a radiologically controlled area. The RWP will be maintained by the Radiological Control Technician at the entrance to the radiologically controlled area. All site workers will be required to be Radiation Worker II-trained to perform work within a radiologically controlled area. 
Revision: 0

Date: April 2013

\subsubsection{Utility Clearances, Excavation Permits, and Blind Penetration Permits}

An excavation/penetration permit will be obtained prior to excavation and penetration activities. The permit requires that a utility clearance be performed. A copy of the permit will be filed on site throughout the duration of the project. 
CAU 366 CAP

Section: Detailed SOW

Revision: 0

Date: April 2013

THIS PAGE INTENTIONALLY LEFT BLANK 


\subsection{SCHEDULE}

All preparation and field activities are scheduled for completion in fiscal year 2013. Sufficient flexibility will be incorporated into the field schedule to allow for minor difficulties

(e.g., weather, equipment failure). The U.S. Department of Energy, National Nuclear Security Administration Nevada Field Office shall notify NDEP of any condition or event that may impact the project schedule. 
CAU 366 CAP

Section: Schedule

Revision: 0

Date: April 2013

THIS PAGE INTENTIONALLY LEFT BLANK 


\subsection{POST-CLOSURE PLAN}

The following CASs will be closed in place with administrative controls, and URs will be implemented to prohibit any unauthorized intrusive activities:

- CAS 11-08-01, Contaminated Waste Dump \#1

- CAS 11-08-02, Contaminated Waste Dump \#2

- CAS 11-23-02, Radioactively Contaminated Area B

- CAS 11-23-03, Radioactively Contaminated Area C

- CAS 11-23-04, Radioactively Contaminated Area D

\subsection{INSPECTIONS}

Annual inspections will be completed at CAU 366. Inspections will consist of visual inspections of the postings to verify they are in place and readable and that the URs have been maintained. The covers at CAS 11-08-01 and CAS 11-08-02 will be inspected for cracks, animal burrows, or other evidence of erosion. Results of the inspections will be included in the combined annual letter report and submitted to NDEP. The annual letter report will include a discussion of observations and a copy of the inspection checklist.

\subsection{MONITORING}

Post-closure monitoring will not be required for CAU 366.

\subsection{MAINTENANCE AND REPAIR}

Any identified maintenance or repair requirements will be reported to NDEP and scheduled within 90 working days of discovery. Repair and maintenance activities will be documented in writing at the time of the repair and summarized in the annual letter report. 
CAU 366 CAP

Section: Post-Closure Plan

Revision: 0

Date: April 2013

THIS PAGE INTENTIONALLY LEFT BLANK 


\subsection{REFERENCES}

Federal Facility Agreement and Consent Order, 1996 (as amended). Agreed to by the State of Nevada; the U.S. Department of Energy, Environmental Management; the U.S. Department of Defense; and the U.S. Department of Energy, Legacy Management.

NNSA/NSO, see U.S. Department of Energy, National Nuclear Security Administration Nevada Site Office.

Radiological Control Managers’ Council, 2012. Nevada National Security Site Radiological Control Manual, DOE/NV/25946--801 Revision 2. March 2012. Las Vegas, NV.

U.S. Department of Energy, National Nuclear Security Administration Nevada Site Office, 2011. Corrective Action Investigation Plan for Corrective Action Unit 366: Area 11 Plutonium Valley Dispersion Sites, Nevada National Security Site, Nevada, DOE/NV--1466. Las Vegas, NV.

U.S. Department of Energy, National Nuclear Security Administration Nevada Site Office, 2012a. Corrective Action Decision Document for Corrective Action Unit 366: Area 11 Plutonium Valley Dispersion Sites, Nevada National Security Site, Nevada, DOE/NV--1488. Las Vegas, NV.

U.S. Department of Energy, National Nuclear Security Administration Nevada Site Office, 2012b. Soils Risk-Based Corrective Action Evaluation Process, DOE/NV--1475.

Las Vegas, NV. 
CAU 366 CAP

Section: References

Revision: 0

Date: April 2013

THIS PAGE INTENTIONALLY LEFT BLANK 


\section{APPENDiX A}

\section{ENGINEERING SPECIFICATION AND DRAWINGS}

NOTE: Engineering specifications and drawings are not required for closure of Corrective Action Unit 366. This Appendix is included as required by the approved Federal Facility Agreement and Consent Order outline for a Corrective Action Plan. 
CAU 366 CAP

Section: Appendix A

Revision: 0

Date: April 2013

THIS PAGE INTENTIONALLY LEFT BLANK 


\section{Appendix B}

\section{SAMPling AND ANALysis Plan}

NOTE: Samples are not required for closure of Corrective Action Unit 366. This appendix is included as required by the approved Federal Facility Agreement and Consent Order outline for a Corrective Action Plan. 
CAU 366 CAP

Section: Appendix B

Revision: 0

Date: April 2013

THIS PAGE INTENTIONALLY LEFT BLANK

B-2 


\section{APPENDiX C}

\section{ACTIVITY ORgANIZATION}


CAU 366 CAP

Section: Appendix C

Revision: 0

Date: April 2013

THIS PAGE INTENTIONALLY LEFT BLANK 
For this activity, the U.S. Department of Energy, National Nuclear Security Administration (NNSA) Nevada Field Office point of contact is as follows:

NNSA Nevada Field Office Activity Lead: Tiffany Lantow

Telephone Number: (702) 295-7645

The identification of the activity Health and Safety Officer and the Quality Assurance Officer can be found in the appropriate plan. However, personnel are subject to change, and it is suggested that the appropriate NNSA Nevada Field Office Activity Lead be contacted for further information. 
CAU 366 CAP

Section: Appendix C

Revision: 0

Date: April 2013

THIS PAGE INTENTIONALLY LEFT BLANK 
CAU 366 CAP

Section: Library Distribution List

Revision: 0

Date: April 2013

\section{LIBRARY DISTRIBUTION LIST}


CAU 366 CAP

Section: Library Distribution List

Revision: 0

Date: April 2013

\section{THIS PAGE INTENTIONALLY LEFT BLANK}


U.S. Department of Energy

Office of Scientific and Technical Information

P.O. Box 62

Oak Ridge, TN 37831-0062

Southern Nevada Public Reading Facility

c/o Nuclear Testing Archive

P.O. Box 98521, M/S 400

Las Vegas, NV 89193-8521

Manager, Northern Nevada FFACO

Public Reading Facility

c/o Nevada State Library \& Archives

Carson City, NV 89701-4285
1 (Uncontrolled, electronic copy)

2 (Uncontrolled, electronic copies)

1 (Uncontrolled, electronic copy) 
CAU 366 CAP

Section: Library Distribution List

Revision: 0

Date: April 2013

\section{THIS PAGE INTENTIONALLY LEFT BLANK}

